\title{
New beaded lacewings (Neuroptera: Berothidae) from Upper Cretaceous Myanmar amber
}

\author{
Dandan Yuan, Dong Ren, Yongjie Wang* \\ College of Life Sciences, Capital Normal University, 105 Xisanhuanbeilu, Haidian \\ District, Beijing 100048, China. \\ *Corresponding author: wangyjosmy@gmail.com
}

\begin{abstract}
Two new genera with two new species in Berothidae, Maculaberotha nervosa gen. et sp. nov. and Magniberotha recurrens gen. et sp. nov., are described from Upper Cretaceous Myanmar (Burmese) amber. Based on the new specimens of the same species, we propose some venational characters as intraspecific variations, e.g., the markings on the wings and crossveins in the radial sector. We also study and compare the female genital sclerites from three genera of Haploberotha, Dasyberotha, and Jersiberotha to highlight the importance of using these characters preserved in amber for taxonomic and phylogenetic studies. Furthermore, an updated key to the berothid genera of Myanmar amber is provided.
\end{abstract}

Keywords: Cretaceous; Myanmar amber; new genus; genitalia

\section{Introduction}


Berothidae, as a relic group of Neuroptera, comprise about 110 extant species in 24 genera (Aspöck and Randolf, 2014). Due to the characteristic raptorial forelegs, this family is generally considered to be related to the other homologous family Rhachiberothidae, which were originally treated as a subfamily of Berothidae for sharing similar venational characters (Tjeder, 1959). Although both groups are easily identified by the specialization of the forelegs, the involvement of Mantispidae with the similar raptorial forelegs raised the question about the relationships of these three families (Willmann, 1990). Aspöck and Mansell firstly clarified the familial status of Rhachiberothidae, and suggested the sister relationships of Berothidae, Rhachiberothidae and Mantispidae (Aspöck and Mansell, 1994), which are supported by the morphological analyses (Aspöck et al., 2001; Beutel et al., 2010; Zimmermann et al., 2011; Randolf et al., 2013, 2014; Aspöck and Randolf, 2014). However, this taxonomy was challenged by the subsequent molecular phylogenetic analysis (Haring and Aspöck, 2004; Winterton, 2010). The Paraberothinae was first established as a subfamily of Rhachiberothidae for its typical raptorial forelegs (Nel et al., 2005). Makarkin et al. did not support the familial status of Rhachiberothidae and treated it as a subfamily (Rhachiberothinae) of the Berothidae and therefore, Paraberothinae was correspondingly regarded as a subfamily of 
Berothidae (Makarkin and Kupryjanowicz, 2010; Makarkin, 2015). Herein, we tentatively follow the morphological results that regard Rhachiberothidae at the family rank (Aspöck and Randolf, 2014) and treat Paraberothinae as a subfamily of Rhachiberothidae.

The fossil record of Berothidae (excluding Rhachiberothidae) is scarce, comprising about 20 genera with about 31 species described from the Middle Jurassic to upper Eocene, they are distributed in Myanmar, Kazakhstan, China, Lebanon, America, Brazil, France, England, Mongolia, Columbia and the Baltic, including amber and compression (Krüger, 1923; Whalley, 1980; Klimaszewski and Kevan, 1986; MartinsNeto and Vulcano, 1990; Makarkin, 1994; Ren and Guo, 1996; Grimaldi, 2000; Engel, 2004; Makarkin, 2004; Engel and Grimaldi, 2008; Makarkin et al, 2011; Azar and Nel, 2013; Khramov, 2015; Makarkin and Ohl, 2015). The oldest convincing berothids were found from the uppermost Middle Jurassic of Daohugou, Inner Mongolia, China (Makarkin et al., 2011). Among various localities with documented berothid fossils, Myanmar amber preserve speciose berothids with high morphological diversity. Engel and Grimaldi have described the Myanmar amber berothids with seven genera and nine species (Engel, 2004; Engel and Grimaldi, 2008).

Up to date, we have collected nearly one hundred berothids from Myanmar amber, which allowed us to conduct a comprehensive study of 
Myanmar amber berothids. In addition, we describe two new genera with two new species, Maculaberotha nervosa gen. et sp. nov. and Magniberotha recurrens gen. et sp. nov. Furthermore, we report the female genital structure of three genera, Haploberotha, Dasyberotha, and Jersiberotha. Meanwhile, some diagnostic characters are regarded as the intraspecific individual variations, e.g. the wing markings, and the crossveins in radial sector.

Based on our analyses, we propose the key diagnostic characters at generic level as followings: wing shape, hairs on the body and wings, the configuration of crossvein r1-rs (number and position), number of Rs branches. We set up a key to the genera from Myanmar amber.

\section{Material and methods}

The amber specimens studied in this paper are from Hukawng Valley in Tanai Village, Myitkyina District of Kachin State, Myanmar (Fig. 1)(Cruickshank and Ko, 2003; Dong et al., 2015). The amber-bearing deposits have been dated to the earliest Cenomanian, circa $98.8 \pm 0.6 \mathrm{Ma}$, based on $\mathrm{U}-\mathrm{Pb}$ radiometric dating of zircons from the volcaniclastic matrix (Shi et al., 2012).

All specimens are housed in the Key Lab of Insect Evolution \& Environmental Changes, the College of Life Sciences, Capital Normal University, Beijing (CNUB; Dong Ren, Curator). The specimens are 
examined using a Leica MZ12.5 dissecting microscope (Leica, Wetzlar, Germany) and illustrated with the aid of a drawing tube attachment. The photographs were taken with an attached Leica DFC500 digital camera system. And the figures were prepared with Adobe Photoshop CS6.

The venational and genital terminology in general follows the interpretation of Aspöck and Aspöck (1996). Venational abbreviations are as follows: C. costa; Sc, subcosta; R1, radius; Rs, radial sector; Rs1-5, first to fifth radial sector branches; Ma, anterior media; Mp, posterior media; $\mathrm{Cu}$, cubitus; $\mathrm{CuA}$, anterior cubitus; $\mathrm{CuP}$ : posterior cubitus; $\mathrm{A}$ : anal; A1-A3, first to third anal veins. Abdominal and genital abbreviations are as follows: T: Tergite; sgp: subgenitale; cc: callus cerci; gl: gonapophysis lateralis; T: Tergite; e: ectoproct; hc: hypocaudae; phc: pseudohypocaudae.

In addition, this work has been registered in Zoobank. The Zoobank LSIDs (Life Science Identifiers) for this work is: urn:Isid:zoobank.org:pub:B2C025D5-1356-4728-B7E7-8F4BE974E73B.

\section{Systematic palaeontology}

Key to genera of Berothidae from Myanmar amber.

1. Crossveins r1-rs present in forewing; forewing typically with sparse setae, rarely with dense setae 
Crossveins r1-rs absent; forewing very densely covered with elongate setae Ethiroberotha Engel and Grimaldi, 2008

2. Only one r1-rs crossvein. 3 More than one r1-rs crossvein (at least two) ............................4

3. Vein Rs with only one branch, flagellum with 21-22 flagellomeres Haploberotha Engel and Grimaldi, 2008

Vein Rs with four branches, flagellum with more than 70 flagellomeres Maculaberotha gen. nov.

4. Distalmost r1-rs crossvein present beyond $\mathrm{Sc}-\mathrm{R}_{1}$ fusion. .5 Distalmost r1-rs crossvein present before $\mathrm{Sc}-\mathrm{R}_{1}$ fusion 6

5 Forewing with numerous setae on margins, sparse over wing surface; not obscuring wing venation; apical rs-rs and rs-m crossveins absent. Body setae short and scattered

Telistoberotha Engel and Grimaldi, 2008 Forewing with dense setae on margins and over surface; apical rs-rs and rs-m present. Body setae dense and elongate. Dasyberotha Engel and Grimaldi, 2008 
6 Forewing narrowly elongate, apex acute; costal space considerably broader basally than apically at Sc-R1 fusion; scape short, as long as wide. Systenoberotha Engel and Grimaldi, 2008

Forewing ovoid, apex broadly round; costal space not broader basally than apically at Sc-R1 fusion; scape 2-3 times as long as wide.............................................................. 7

7 Humeral vein simple, not recurrent; Rs with less than three branches .8

Humeral vein recurrent; Rs with four or five branches Magniberotha gen. nov.

8. Forewing with distinct areas of infuscation surrounding crossveins and vein forks, some or all crossveins simple prior to Sc-R1 fusion; one ma-mp crossvein and one cua-cup crossvein present (except $J$. tauberorum); veins stronger..................Jersiberotha Engel and Grimaldi, 2008

Forewing lacking areas of infuscation; all c-sc crossveins simple prior to Sc-R1 fusion; ma-mp crossvein and cua-cup crossvein absent. Iceloberotha Engel and Grimaldi, 2008

Class: Insecta Linnaeus, 1758

Order: Neuroptera Linnaeus, 1758 
Family: Berothidae Handlirsh, 1906

Genus Maculaberotha gen. nov.

Maculaberotha gen. nov. urn:lsid:zoobank.org:act:48C5D495-60834B4C-B8DF-2CFE493636C6.

Etymology. The generic name is from the Latin "macula" (meaning "maculate"), in reference of some scattered patches along veins. "Berotha", a genus name of the family Berothidae. Gender feminine.

Type species: Maculaberotha nervosa sp. nov.

(Figs. 2-3).

Diagnosis. Body size small, but distinctly shorter than the forewing. Flagellum with 71 flagellomeres. Most veins irregularly mottled with fuscous markings. Costal crossveins simple, with a few distal forks. Humeral veinlet slightly recurrent. Single r1-rs crossvein. Rs with four branches, and a few crossveins throughout the radial sector.

Remarks. Maculaberotha gen. nov. is distinctly different from the other Myanmar berothid genera by having one r1-rs crossvein: Ethiroberotha (absence of r1-rs), Jersiberotha, Iceloberotha, Telistoberotha and Dasyberotha (with two r1-rs). Although Haploberotha has only a single r1-rs, but it is obviously different from the new genus: (1) the body size in the new genus (body length $3.0 \mathrm{~mm}$ and forewing length $4.3 \mathrm{~mm}$ ) is larger than the body size in Haploberotha (body length 
$1.93 \mathrm{~mm}$ and forewing length $2.14 \mathrm{~mm}$ ); (2) flagellum with 71 flagellomeres in the new genus vs. only 21-22 flagellomeres in Haploberotha; (3) Rs with four branches in the new genus vs. only one branch in Haploberotha; (4) veins irregularly mottled with fuscous markings in the new genus vs. veins with uniform coloration.

Maculaberotha nervosa gen. et sp. nov. (Figs. 2-3). urn:1sid:zoobank.org:act:44517EF5-D415-4BB6-8924-31235DEA2283.

Etymology. From the Latin "nervosus", in reference of the multiple Rs branches.

Type material. Holotype, CNU-NEU-MA2016003, (Figs. 2-3). Female, body preserved incompletely, but four wings spreading.

Locality and horizon. Hukawng Valley, Kachin State, Northern Myanmar; lowermost Cenomanian, Upper Cretaceous.

Diagnosis. As for genus.

Description. Female, total body length $3.0 \mathrm{~mm}$. Head and body with numerous scattered, fine setae. Scape elongate, about 3 to 4 times as long as wide; flagellum with 71 flagellomeres; flagellomeres with a few, relatively long setae arranged in a circle. The maxillary palpus well preserved, and the apical segment elongated and acutely pointed (Fig. 2C). Pronotum narrow, a little longer than width; meso- and metanotum as long as wide. Legs slender and covered by numerous hairs. The first 
six abdominal segments unmodified, and the other segments deformed. Tergite 9 probably fused with ectoproct (Fig. 2D).

Forewing: left forewing $4.3 \mathrm{~mm}$ in length, $1.7 \mathrm{~mm}$ in width; right forewing, $4.8 \mathrm{~mm}$ in length, $1.8 \mathrm{~mm}$ in width (the difference of both wings is likely due to preservation in amber). Membrane hyaline and some scattered patches along veins. Wing apex broadly rounded. Trichosors and microtrichia prominent along the entire wing margin. Veins covered by numerous long hairs. Humeral vein slightly recurrent. Costal crossveins simple, with occasional forks. Sc distally amalgamated with R1. One sc-r1 crossvein present between the points of Rs and Mp diverged from R1. Rs with four primary branches, and few crossveins present in the radial sector. Only one r1-rs crossvein distant from the base, located beyond the separation of $\mathrm{Rs}_{4}$. Ma forming the simple distal biforks. Single ma-mp crossvein situated before the divergence of Ma from Rs. Mp deeply forked, and $\mathrm{Mp} 1$ and $\mathrm{Mp} 2$ forming the distal dichotomous forks. Two crossveins (mp-cu) present between $\mathrm{Mp} 2$ and $\mathrm{CuA}$. $\mathrm{Cu}$ deeply branched; $\mathrm{CuA}$ forming the distal dichotomous forks, and CuP deeply forked, and with three pectinate branches. A1 with four distal pectinate branches, and A2 with six pectinate branches, A3 not detected.

Hind wing: left hind wing $4.2 \mathrm{~mm}$ in length, $1.8 \mathrm{~mm}$ in width; right hind wing $4.5 \mathrm{~mm}$ in length, $1.8 \mathrm{~mm}$ in width. Trichosors well distributed 
along the margin. Costal space narrow, and slightly dilated in distal. $\mathbf{R}_{1}$ space broad, slightly wider than costal space. Costal crossveins simple. Single r1-rs distant from the wing base. Rs with three branches. Ma forked distantly. Mp with deep branches, $\mathrm{Mp} 1$ branched in one-third near the wing base. $\mathrm{CuA}$ almost parallel to hind margin, and pectinately branched.

Magniberotha gen. nov. urn:1sid:zoobank.org:act:DC068DB6-4FBA410E-9490-1077CA31793D.

Etymology. The generic name is from the Latin "magnus" (meaning "large"), in reference its large body size. "Berotha", a genus name of the family Berothidae. Gender feminine.

Type species: Magniberotha recurrens sp. nov.

(Figs. 4-6)

Diagnosis. Small body size as long as the wing ( $>4 \mathrm{~mm}$ ); forewing elongate; humeral veinlet recurrent; Rs with four or five branches; two r1-rs crossveins, and proximal r1-rs present at wing midpoint, and slightly beyond the divergence of $\mathrm{Rs}_{2}$ branch, distal $\mathrm{r} 1-\mathrm{rs}$ crossvein situated before Sc-R1 fusion; Ma separated from Rs at one third of the wing; $\mathrm{Cu}$ vein proximally branched; $\mathrm{CuA}$ dichotomously branched near the middle of wing, and $\mathrm{CuP}$ proximally branched and forming three further branches. 
Remarks. Magniberotha gen. nov. has the body size $>4 \mathrm{~mm}$ in comparison with other berothids from Myanmar amber (not exceeding $3.2 \mathrm{~mm})$. Notably, it is the first time to detect the recurrent humeral veinlet within the Myanmar amber berothids regardless of the relatives of Rhachiberothidae. In nature, the recurrent humeral veinlet is widely found in both extant and fossil (main in compression fossil) berothids, and it indicates the condition of recurrent veinlet is likely also common in the Myanmar amber berothids. Additionally, the new genus has two r1-rs crossveins in forewing, which is distinctly different with two other Myanmar berothids, Ethiroberotha (absence of r1-rs), and Haploberotha (only with a single r1-rs). Although Telistoberotha and Dasyberotha also have two r1-rs crossveins, the locations of r1-rs for both genera are conspicuously different from that of the new genus: distalmost r1-rs beyond $\mathrm{Sc}-\mathrm{R}_{1}$ fusion vs. distalmost $\mathrm{r} 1-\mathrm{rs}$ present before $\mathrm{Sc}-\mathrm{R} 1$ fusion (new species).

Magniberotha recurrens gen. et sp. nov. (Figs. 4-6) urn:1sid:zoobank.org:act:8FC413EA-B3A8-45B8-9904-E1C594802851.

Etymology. From the Latin "recurrens", in reference to its recurrent humeral veinlets.

Type material. Holotype, CNU-NEU-MA2016001, (Fig. 4). Female, body well preserved with incomplete antenna, wings and parts of legs. 
Paratype, CNU-NEU-MA2016002, (Fig. 5). Amber with complete body and unilateral wings preserved.

Locality and horizon. Hukawng Valley, Kachin State, Northern Myanmar; lowermost Cenomanian, Upper Cretaceous.

Diagnosis. As for genus.

Description. Female. Length of body exceeding $4.0 \mathrm{~mm}$. Head deformed due to preservation. Antennae moniliform, incompletely preserved; flagellum with 28 flagellomeres preserved and the apical tapered (Figs. 4A and 4B). Abdomen with nine segments, and the first seven tergites relatively small, and $8^{\text {th }}$ tergite broad (Fig. 4C). Subgenitale (sgp) with a pair of ventral triangular ridges on both sides. $9^{\text {th }}$ tergite and ectoproct incorporated as a large tergite. The possible callus cerci (cc) round and with many long hairs. The gonapophysis laterals (gl) simple and fingerlike, absence of hypocauda.

Forewing $4.3 \mathrm{~mm}$ in length, and $1.7 \mathrm{~mm}$ in width. Dense hairs and trichosors present along the margin. Membrane hyaline, without any markings. Costal space relatively broad, especially at proximal one third and distalmost Sc- $\mathrm{R}_{1}$ fusion. Humeral veinlet recurrent. Costal crossveins simple, with some occasional distal forks. Sc and R1 distally anastomosed and entering the margin before the apex. Single sc-r1 crossvein located at the proximal of wing, just after origin of Rs (separated from Rs by less than crossvein length). Two r1-rs crossveins, 
and the proximal one present at the middle of wing, situated near the divergence of $\mathrm{Rs}_{2}$. Rs with four branches, and each branch shallowly forked. Ma separated from Rs one-third from wing base, and forming the simple distal dichotomous forks. Two crossveins present between Ma and Mp. Mp forking proximally, and Mp1 and Mp2 deeply dichotomously branched. Three crossveins present between $\mathrm{Mp} 2$ and $\mathrm{CuA} . \mathrm{CuA}$ and $\mathrm{CuP}$ diverged close to wing base. One cua-cup just located after the second branching point of $\mathrm{CuP}$. CuA dichotomously branched near the middle of wing, and $\mathrm{CuP}$ proximally deeply branched and forming three pectinate branches. One cup- $\mathrm{a}_{1}$ present close to the wing base. A1, A2 and A3 wellpreserved, A2 pectinately branched, with 7 simple branches.

Hind wing length $3.5 \mathrm{~mm}$, width $1.4 \mathrm{~mm}$. Hind wing elongate. Costal space narrowed from the base to middle, and dilated distally, especially close to Sc- $\mathrm{R}_{1}$ fusion. One $\mathrm{r} 1-\mathrm{rs}$ situated before $\mathrm{Sc}-\mathrm{R}_{1}$ fusion, no other crossvein detected. Rs with four primary branches, and $\mathrm{Rs}_{1}$ deeply branched. Mp proximally forking. CuA partly preserved, forming the pectinate branches.

\section{Discussion}

The Cretaceous Myanmar amber, as reported so far, show speciose berothids with high morphological diversity in comparison with those of berothids from other localities. As for most extinct winged insects, these 
Myanmar berothids were also classified primarily according to the venational features, while the characters of genitalia were rarely used for classification mainly due to the lack of or limited preservation in the fossil insects. Nevertheless, it is quite likely that the genitalia of amber insects are better preserved and easier to be discerned in contrast to the compression fossils. Therefore, amber insects offer new insights on the identification, systematics, phylogeny to gain better understanding of the early development and evolution of extinct insects (Krivokhatsky, 2002; Lu et al, 2016).

As for the Cretaceous Myanmar amber berothids, a serious issue surfaced that the diagnosis and description of some taxa (particularly at species level) became obscure when more materials were examined. For instance, the genus Jersiberotha was firstly erected by Grimaldi from the New Jersey amber for sharing the wing characters: two adjacent $\mathrm{r} 1$-rs crossveins in the forewing, only one mp1-mp2 crossvein (Grimaldi, 2000). In 2008, Engel and Grimaldi described two other species ( $J$. myanmarensis and J. tauberorum) and a related genus Iceloberotha from Myanmar amber based on the diagnostic characters of venation, i.e. speckless forewing in Iceloberotha vs distinctly spotted forewing in Jersiberotha; absence of crossvein ma-mp and cua-cup in Iceloberotha vs. presence of ma-mp and cua-cup in Jersiberotha (referring to the key to genera in Engel and Grimaldi, 2008). Nevertheless, it is evident that 
these characters occurred mosaically in both genera, e.g. the Myanmar species $J$. tauberorum clearly loses the crossveins mp1-mp2 and cua-cup, while the type species of Iceloberotha has an evident mp1-mp2 crossvein in the original drawings (Engel and Grimaldi, 2008: figs. 21, 24). Additionally, the specimens in Fig. 7 are conspicuously related to Jersiberotha for the well-developed crossveins mp1-mp2 and cua-cup, however the speckless forewing in Figs. 7C, D indicates they also have the possible affinities to Iceloberotha. Consequently, it is difficult to identify the species of these two genera merely based on the venational characters. In Engel and Grimaldi (2008), a photo of male terminalia in $J$. myanmarensis was provided to show an elongated penisfilum out of the abdomen, but unfortunately it was not clearly visible in other related species to allow a comparison of the genitalia of these specimens. Therefore, future findings of new specimens with discernable genitalia will be a potential way to clarify the systematic status of these two genera.

To date, the genitalia of the Myanmar amber berothids (except for rhachiberothids) were not studied except for the recent works by Makarkin and Ohl (2015). Herein, we describe three types of structural homologous female genitalia based on our new materials, referring to three genera Dasyberotha, Haploberotha and Jersiberotha (Fig. 8), because the genitalia structures of these three genera are well preserved. 
Figs. 8A, B show a female specimen of Dasyberotha, which possesses a pair of club-shape pseudohypocaudae (phc), fused tergite 9 and the stout gonapophyses laterales without hypocaudae. The terminalia of Haploberotha is slightly different from those of Dasyberotha. A pair of digitiform pseudohypocaudae protrudes ventrally from the tergite 9, while the gonapophyses laterales slightly elongate, with a short hypocaudae (Figs. 8C, D). But in Jersiberotha (Figs. 8E, F), the terminalia shape is different from Dasyberotha and Haploberotha. Pseudohypocaudae is very slender, gradually tapering to bluntly pointed top. The gonapophyses laterales are equipped with cephalically directed hypocaudae, slender and acute. Although their female genitalia show different shapes, the similar structure implies their close affiliations for sharing the well-developed pseudohypocaudae and absence of the hypocaudae. The pseudohypocaudae also exists in Rhachiberothidae which is characterized by their rapitorial forelegs (Aspöck and Aspöck, 2008). It seems the three genera are most similar to Protobiellinae for venation and female genitalia, e.g. round and broad wing apex, simple and unforked costal crossveins before Sc-R1 fusion, less Rs branches, well-developed pseudohypocaudae and absence of hypocaudae (Aspöck and Aspöck, 1985). While the female genitalia in the new genera Magniberotha and Maculaberotha seems to be more related to Berothinae, for absence of pseudohypocaudae and the well-developed 
elongated hypocaudae. It is clear that the female genitalia in Myanmar amber berothids had been diversified in the Early Cretaceous. This work is just a preliminary analysis of the female genitalia in the Myanmar amber berothids, and it is hoped that more evidence of the genitalia of the amber berothids will be described in the future research.

\section{Conclusion}

Two new fossil genera and species, Maculaberotha nervosa gen. et sp. nov. and Magniberotha recurrens gen. et sp. nov., are described from the Upper Cretaceous Myanmar amber. An updated key to the known Myanmar amber berothids is provided. Additionally, the female genital structures of three genera are illustrated for the first time. In the previous research and taxonomy of fossil Berothidae, the classification of species was primarily based on venational features while the genital structures were rarely used. It is proposed that the genital character should not be overlooked, especially in the amber specimens.

\section{Acknowledgements}

We thank for Dr. Chungkun Shih (College of Life Sciences, Capital Normal University) for improving the manuscript. We thank Mr. Jun Li for his generous donation of the Myanmar amber specimens and other amber insects for our studies. We appreciate the valuable comments and 
useful suggestion on our manuscript from reviewers and the editor. This work was supported by the National Basic Research Program of China (973 Program) (2012CB821906), National Science Foundation of China (grants 31230065, 31272352, 31301905, 41372013 and 41272006), China Postdoctoral Science Foundation (grant 2012T50113), Research Fund for the Doctoral Program of Higher Education of China (grant 20131108120005), Beijing Natural Science Foundation (grant 5132008),

Great Wall Scholar and KEY project of the Beijing Municipal Commission of Education (KZ201310028033), and Program for Changjiang Scholars and Innovative Research Team in University (IRT13081).

\section{Reference}

Aspöck, U., Aspöck, H., 1985. Die Berothiden Australiens (und Neuseeands) II: Die Genera Trichoma Tillyard, Trichoberotha Handschin, Protobiella Tillyard und Austroberothella n. g. (Neuropteroidea: Planipennia: Berothidae). Zeitschrift der Arbeitsgemeinschaft Österreichischer Entomologen 36, 65-85.

Aspöck, U., Mansell, M.W., 1994. A revision of the family Rhachiberothidae Tjeder, 1959, stat. n. (Neuroptera). Systematic Entomology 19, 181-206.

Aspöck, U., Aspöck, H., 1996. Revision des genus Podallea Navás, 1936 (Neuroptera: Berothidae: Berothinae). Mitteilungen der Münchener Entomologischen Gesellschaft 86, 99-144.

Aspöck, U., Plant, J.D., Nemeschkal, H.L., 2001. Cladistic analysis of Neuroptera and their systematic position within Neuropterida (Insecta: Holometabola: Neuropterida: Neuroptera). Systematic Entomology 26, 73-86.

Aspöck, U., Aspöck, H., 2008. Phylogenetic relevance of the genital sclerites of Neuropterida (Insecta: Holometabola). Systematic Entomology 33, 97-127.

Aspöck, U., Randolf, S., 2014. Beaded lacewings - a pictorial identification key to the genera, their biogeographics and a phylogenetic analysis (Insecta: Neuroptera: Berothidae). Deutsche Entomologische Zeitschrift, 61, 155-172.

Azar, D., Nel, A., 2013. A new beaded lacewing from a new Lower Cretaceous amber outcrop in Lebanon (Neuroptera: Berothidae). In: Azar, D., Engel, M.S., 
Jarzembowski, E., Krogmann, L., Nel, A. and Santiago-Blay, J. (Eds.), Insect evolution in an amberiferous and stone alphabet. Proceedings of the 6th international congress on fossil insects, arthropods and amber. Brill, Leiden and Boston, pp. 111-130.

Beutel, R.G., Friedrich, F., Aspöck, U., 2010. The larval head of Nevrorthidae and the phylogeny of Neuroptera (Insecta). Zoological Journal of the Linnean Society 158, 533-562.

Cruickshank, R. D. and Ko, K., 2003. Geology of an amber locality in the Hukawng Valley, Northern Myanmar. Journal of Asian Earth Sciences 21,441-455.

Dong, F., Shih, C.K., Ren, D., 2015. A new genus of Tanyderidae (Insecta: Diptera) from Myanmar amber, Upper Cretaceous. Cretaceous Research 54, 260-265.

Engel, M.S., 2004. Thorny lacewings (Neuroptera: Rhachiberothidae) in Cretaceous amber from Myanmar. Journal of Systematic Palaeontology 2, 137-140.

Engel, M.S. and Grimaldi, D.A., 2008. Diverse neuropterida in Cretaceous amber, with particular reference to the paleofauna of Myanmar (Insecta). Nova Supplementa Entomologica 20, 1-86.

Grimaldi, D.A., 2000. A diverse fauna of Neuropterodea in amber from the Cretaceous of New Jersey. In: Grimaldi D.A. (Ed.), Studies on fossil in amber, with particular reference to the Cretaceous of New Jersey. Backhuys Publishers, Leiden, pp. 259-303.

Handlirsch, A., 1906-1908. Die fossilen insekten und die phylogenie der rezenten Formen. Ein Handbuch für Palaeontologen und Zoologen. W. Engelmann, Leipzig, $1430 \mathrm{pp}$.

Haring, E., Aspöck, U., 2004. Phylogeny of the Neuropterida: a first molecular approach. Systematic Entomology 29, 415-430.

Khramov, A.V., 2015. Jurassic beaded lacewings (Insecta: Neuroptera: Berothidae) from Kazakhstan and Mongolia. Paleontological Journal 49(1), 26-34.

Klimaszewski, J., Kevan, D.K.M., 1986. A new lacewing-fly (Neuroptera: Planipennia) from Canadian Cretaceous Amber, with an analysis of its fore wing characters. Entomological News 97, 124-132.

Krivokhatsky, V. A., 2002. Musculature of Male Genitalia of Antlions (Neuroptera, Myrmeleontidae): First Results of Study. Acta Zoologica Academiae Scientiarum Hungaricae 48(2), 141-147.

Krüger, L., 1923. Neuroptera succinica baltica. Die im baltischen Bernstein eingeschlossenen Neuroptera des Westpreussischen Provinzial-Museums (heute Museum für Naturkunde und Vorgeschichte) in Danzig. Stettiner Entomologische Zeitung 84, 68-92.

Makarkin, V.N., 1994. Upper Cretaceous Neuroptera from Russia and Kazakhstan. Annales de la Societe Entomologique de France 30(3), 238-292.

Makarkin, V.N., 2004. New genus of minute Berothidae (Neuroptera) from Early Eocene amber of British Columbia. The Canadian Entomologist 136, 61-76.

Makarkin, V.N. and Kupryjanowicz, J., 2010. A new mantispid-like species of Rhachiberothinae from Baltic amber (Neuroptera, Berothidae), with a critical review of the fossil record of the subfamily. Acta Geologica Sinica, 84, 655-664. 
Makarkin, V.N., Yang, Q., Ren, D., 2011. Two new species of Sinosmylites Hong (Neuroptera: Berothidae) from the Middle Jurassic of China, with notes on Mesoberothidae. ZooKeys 130, 199-215.

Makarkin, V.N., Ohl, M., 2015. An important new fossil genus of Berothinae (Neuroptera: Berothidae) from Baltic amber. Zootaxa 3946(3), 401-415.

Makarkin, V.N., 2015. A new genus of the mantispid-like Paraberothinae (Neuroptera: Berothidae) from Myanmar amber, with special consideration of its probasitarsus spine-like setation. Zootaxa 4007 (3), 327-342.

Martins-Neto, R.G., Vulcano, M.A., 1990. Neurópteros (Insecta: Planipennia) da formação Santana (Cretáceo inferior), bacia do Araripe, nordeste do Brasil. III. Superfamília Mantispoidea. Revista Brasileira de Entomologia 34, 619-625.

Nel, A., Perrichot, V., Azar, D. and Néraudeau, D., 2005. New Rhachiberothidae (Insecta: Neuroptera) in Early Cretaceous and Early Eocene ambers from France and Lebanon. Neues Jahrbuch ffh Geologie und Pald Pal und Abhandlungen, 235, $51-85$.

Randolf, S., Zimmermann. D., Aspöck. U., 2013. Head anatomy of adult Sisyra terminalis (Insecta: Neuroptera: Sisyridae) - functional adaptations and phylogenetic implications. Arthropod Structure and Development 42, 565-582.

Randolf, S., Zimmermann. D., Aspöck. U., 2014. Head anatomy of adult Nevrorthus apatelios and basal splitting events in Neuroptera (Neuroptera: Nevrorthidae). Arthropod Systematics and Phylogeny 72(2), 111-136.

Ren, D., Guo, Z.G., 1996. On the new fossil genera and species of Neuroptera (Insecta) from the Late Jurassic of northeast China. Acta Zootaxonomica Sinica 21, 461-479.

Shi, G., Grimaldi, D.A., Harlow, G.E., Wang, J., Wang, J., Yang, M., Lei, W., Li, Q. and Li, X., 2012. Age constraint on Myanmar amber based on U-Pb dating of zircons. Cretaceous Research 37, 155-163.

Tjeder, B., 1959. Neuroptera-Planipennia. The lace-wings of Southern Africa. 2. Family Berothidae. In: Hanstrom, B., Brinck, P. and Rudebec, G. (Eds.), South African animal life. Vol. 6. Swedish Natural Science Research Council, Stockholm, pp. 256-314.

Whalley, P.E.S., 1980. Neuroptera (Insecta) in amber from the Lower Cretaceous of Lebanon. Bulletin of the British Museum of Natural History (Geology) 33, 157164.

Willmann, R., 1990. The phylogenetic position of the Rhachiberothinae and the basal sister-group relationships within the Mantispidae (Neuroptera). Systematic Entomology 15, 253-265.

Winterton, S.L., 2010. A new species of Stenobiella Tillyard (Neuroptera, Berothidae) from Australia. ZooKeys 64, 1-8.

Lu, X.M., Zhang, W.W., and Liu, X.Y., 2016. New long-proboscid lacewings of the mid-Cretaceous provide insights into ancient plant-pollinator interactions. Scientific Report 6, 25382.

Zimmermann, D., Randolf, S., Metscher, B.D., Aspöck, U., 2011. The function and phylogenetic implications of the tentorium in adult Neuroptera (Insecta). Arthropod Structure and Development 40, 571-582. 


\section{Figure captions}

Fig. 1. Map of the amber locality near Tanai in Hukawng Valley (after Dong et al., 2015).

Fig. 2. Holotype of Maculaberotha nervosa gen. et sp. nov. (CNU-NEUMA2016003). A. Photograph of the holotype. B. Details of forewing. C. Details of antenna. D. Details of abdomen. Scale bars $=1 \mathrm{~mm}$.

Fig. 3. Drawing of the holotype of Maculiberotha nervosa gen. et sp. nov. Scale bar = $1 \mathrm{~mm}$.

Fig. 4. Holotype of Magniberotha recurrens gen. et sp. nov. (CNU-NEUMA2016001). A. Photograph of the holotype. B. Details of antenna. C. Details of abdomen. Scale bar $=1 \mathrm{~mm}(\mathrm{~A})$ and $0.5 \mathrm{~mm}(\mathrm{~B}, \mathrm{C})$.

Fig. 5. Paratype of Magniberotha recurrens gen. et sp. nov. (CNU-NEUMA2016002). A. Details of forewing. B. Details of antenna. Scale bar $=1 \mathrm{~mm}$ (A) and $0.5 \mathrm{~mm}(\mathrm{~B})$.

Fig. 6. Fore (above) and hind (below) wing venation of Magniberotha recurrens gen. et sp. nov. Setation omitted. Scale bar $=1 \mathrm{~mm}$.

Fig. 7. Examined specimens of Jersiberotha and Iceloberotha. A. CNU-NEUMA2016004. B. CNU-NEU-MA2016005. C. CNU-NEU-MA2016006. D. CNUNEU-MA2016007. Scale bars $=1 \mathrm{~mm}$.

Fig. 8. A. Examined specimen of Dasyberotha eucharis. CNU-NEU-MA2016008. B. Genital structure of Dasyberotha eucharis. C. Examined specimen of Haploberotha persephone. CNU-NEU-MA2016009. D. Genital structure of Haploberotha persephone. E. Examined specimen of Jersiberotha myanmarensis. CNUNEUMA2016010. F. Genital structure of Jersiberotha myanmarensis. Scale bars $=1$ $\mathrm{mm}$. 
Figure 1

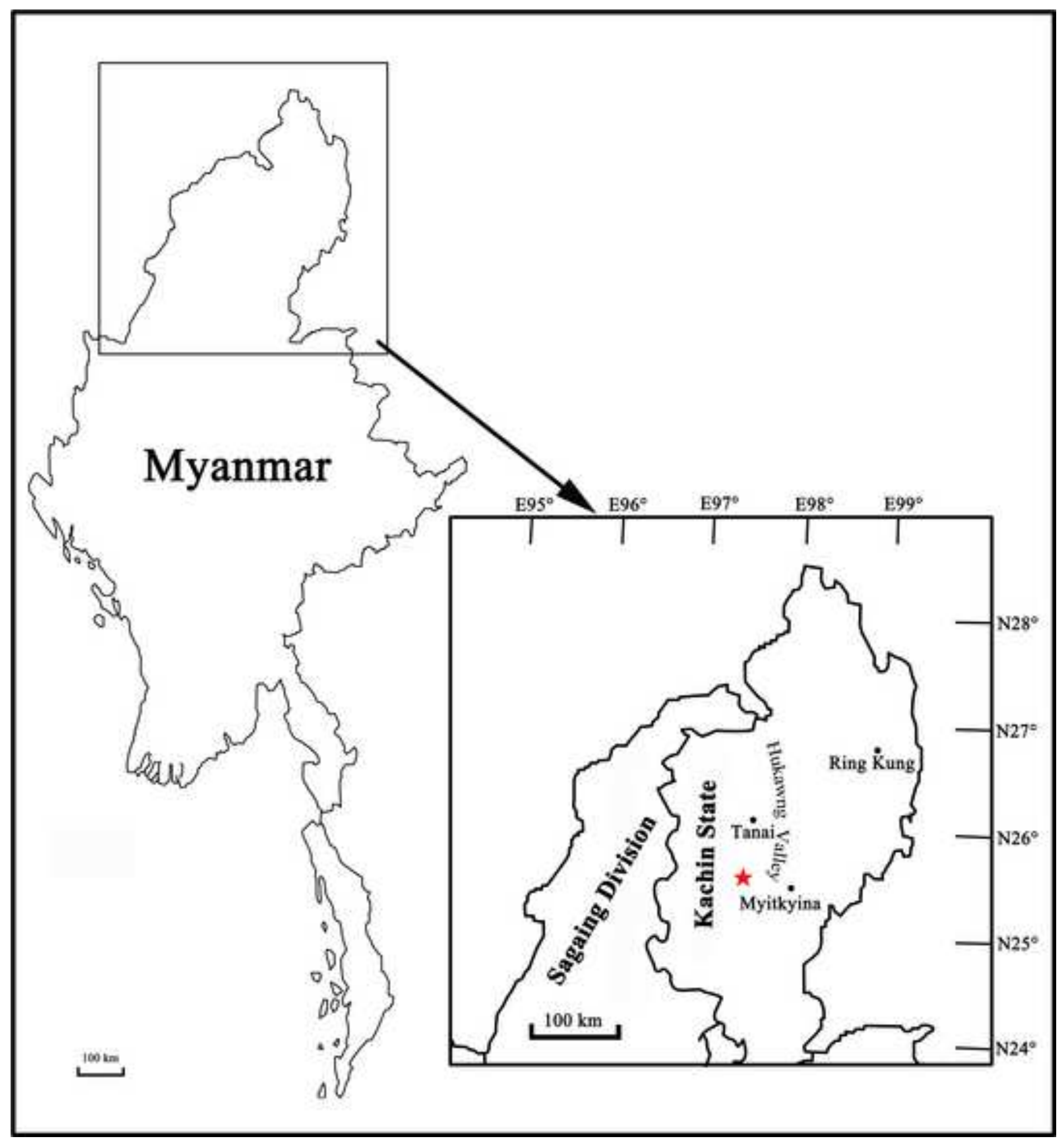




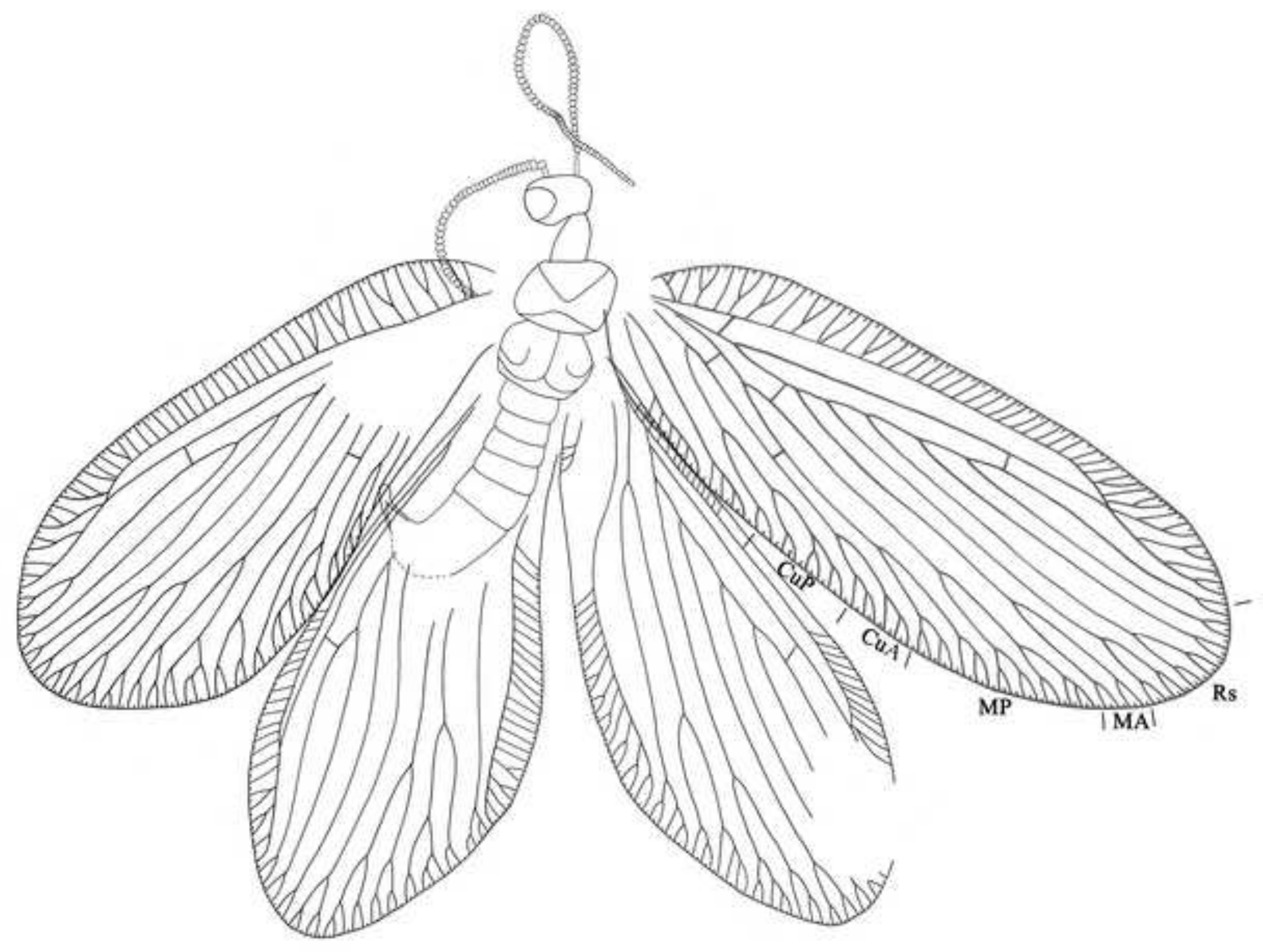




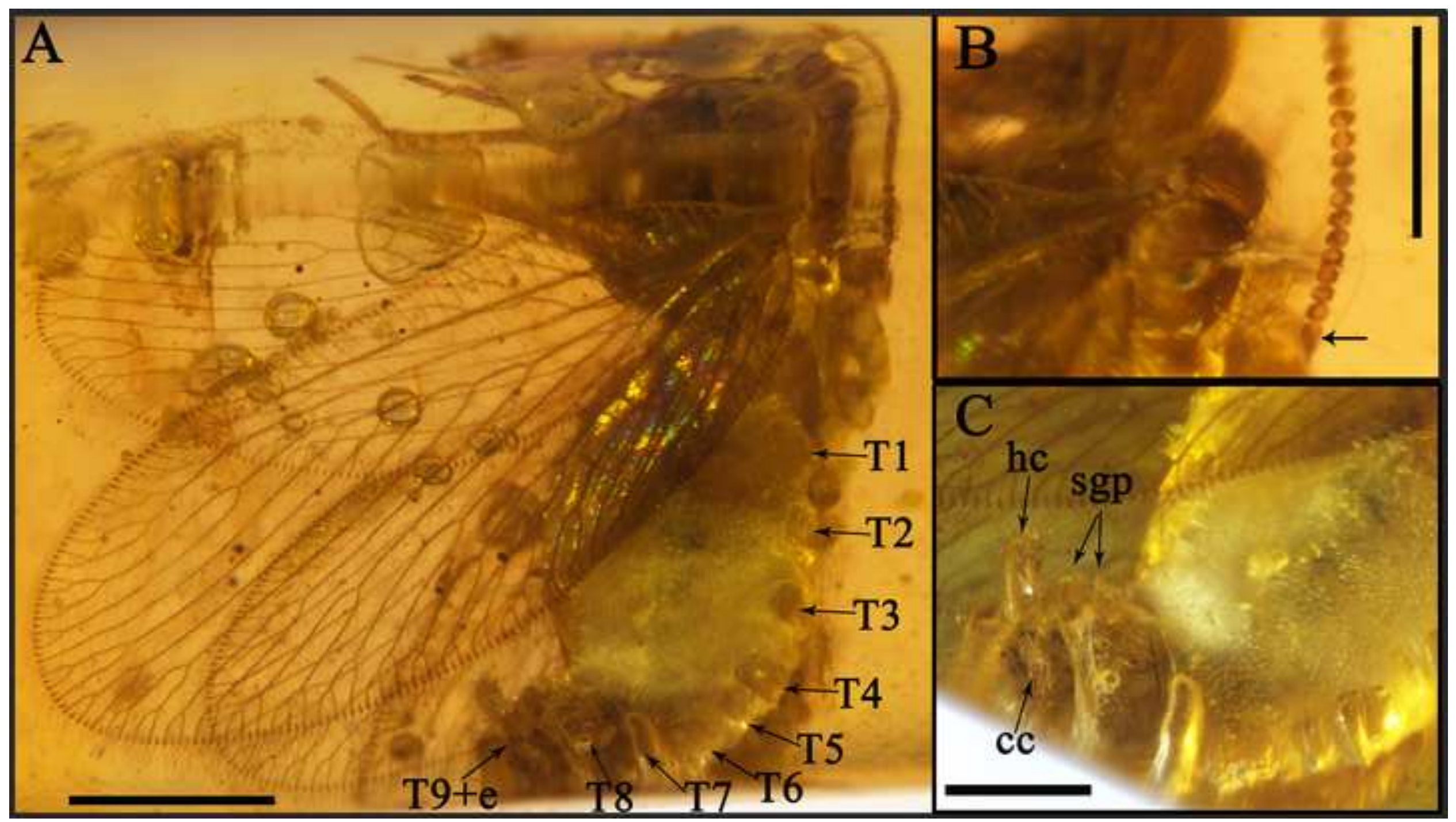




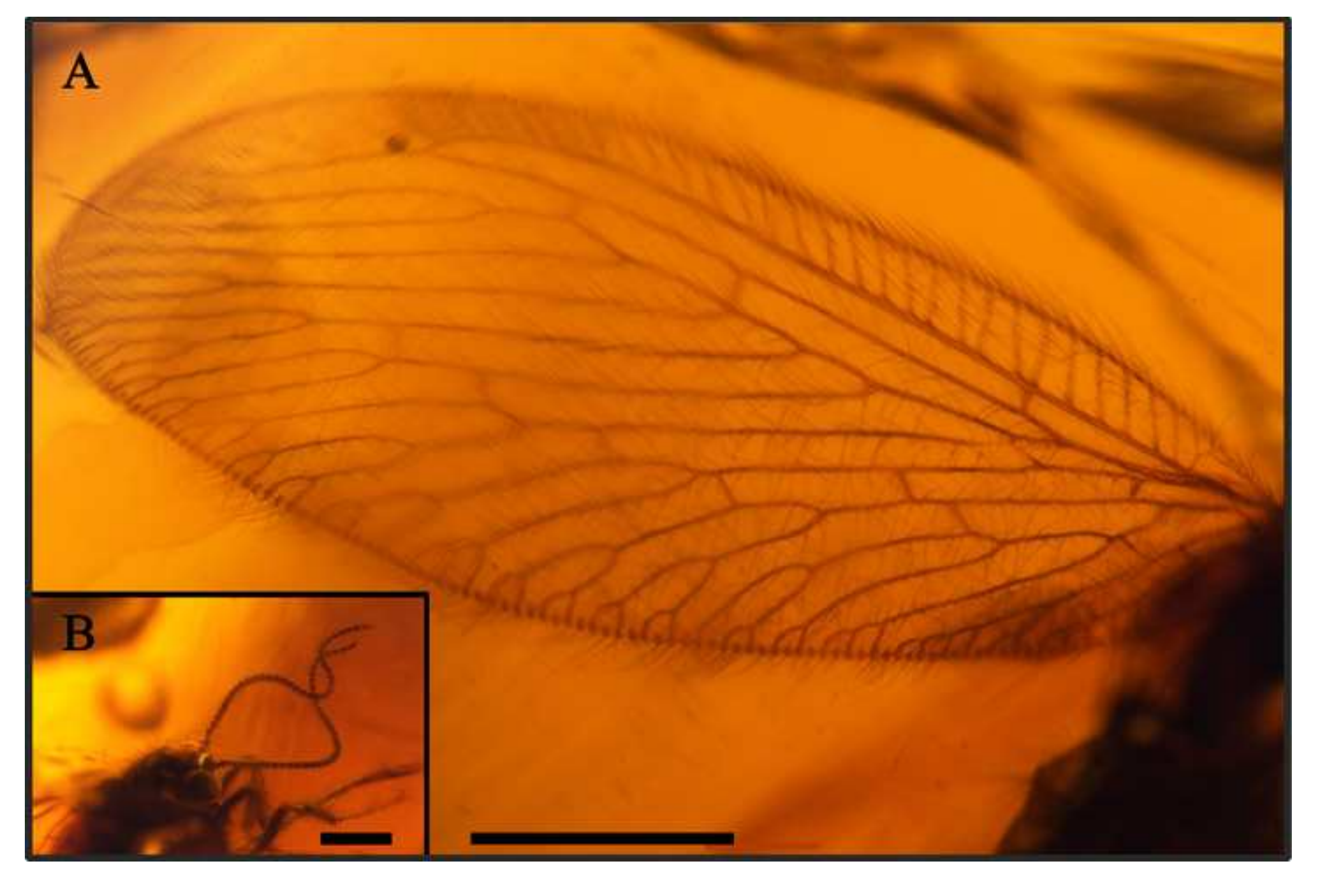

Figure 5 

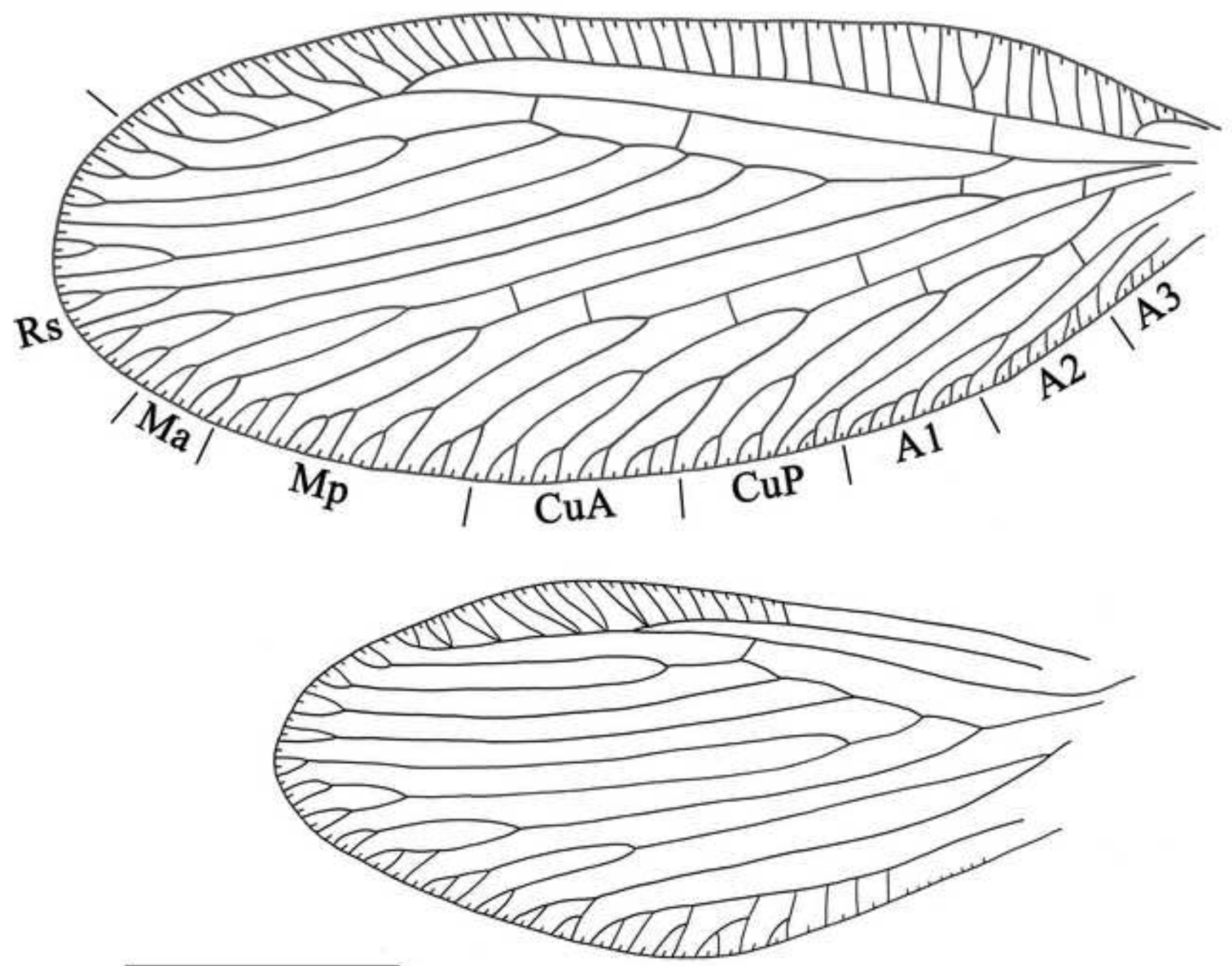


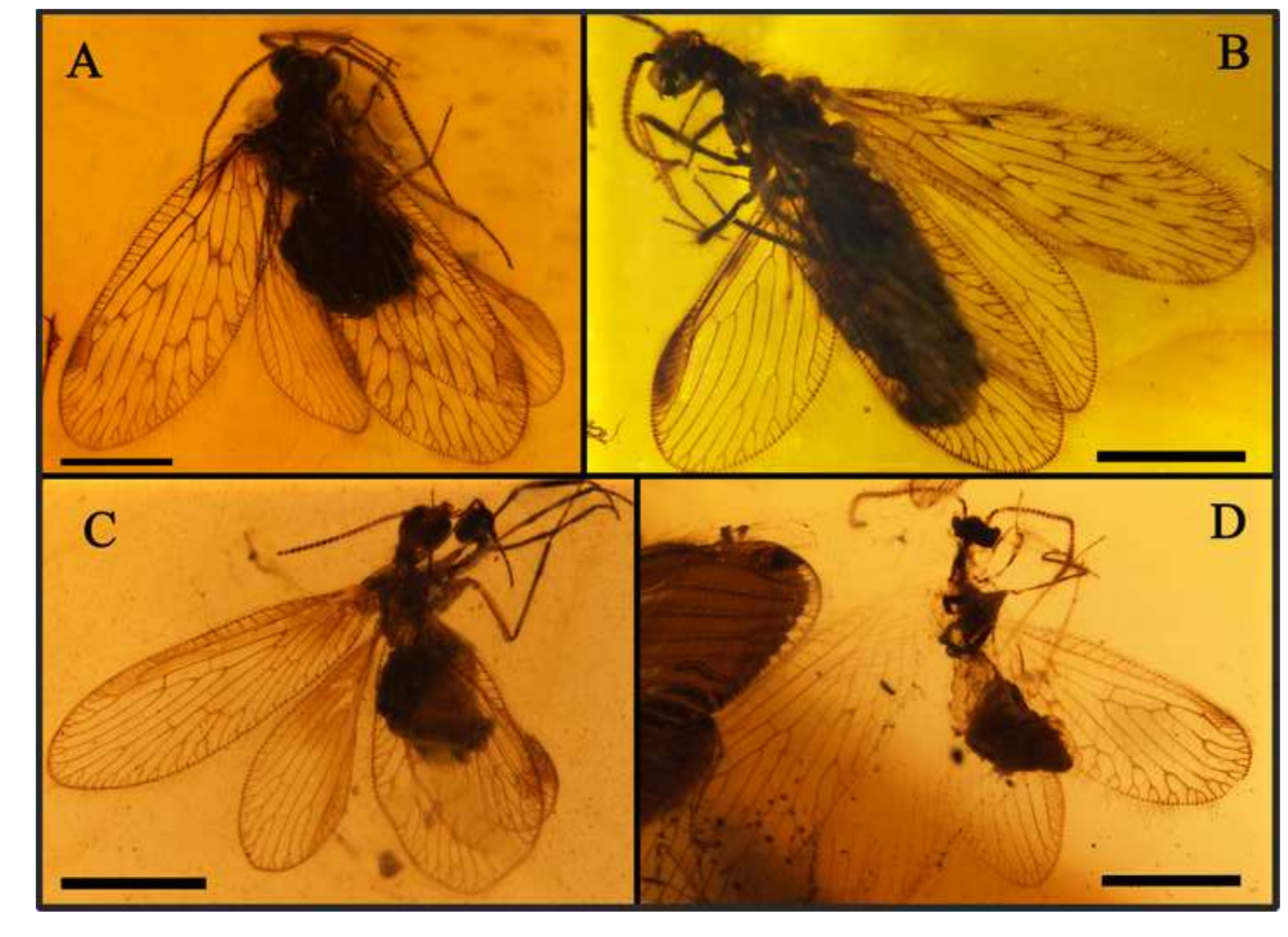

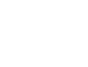




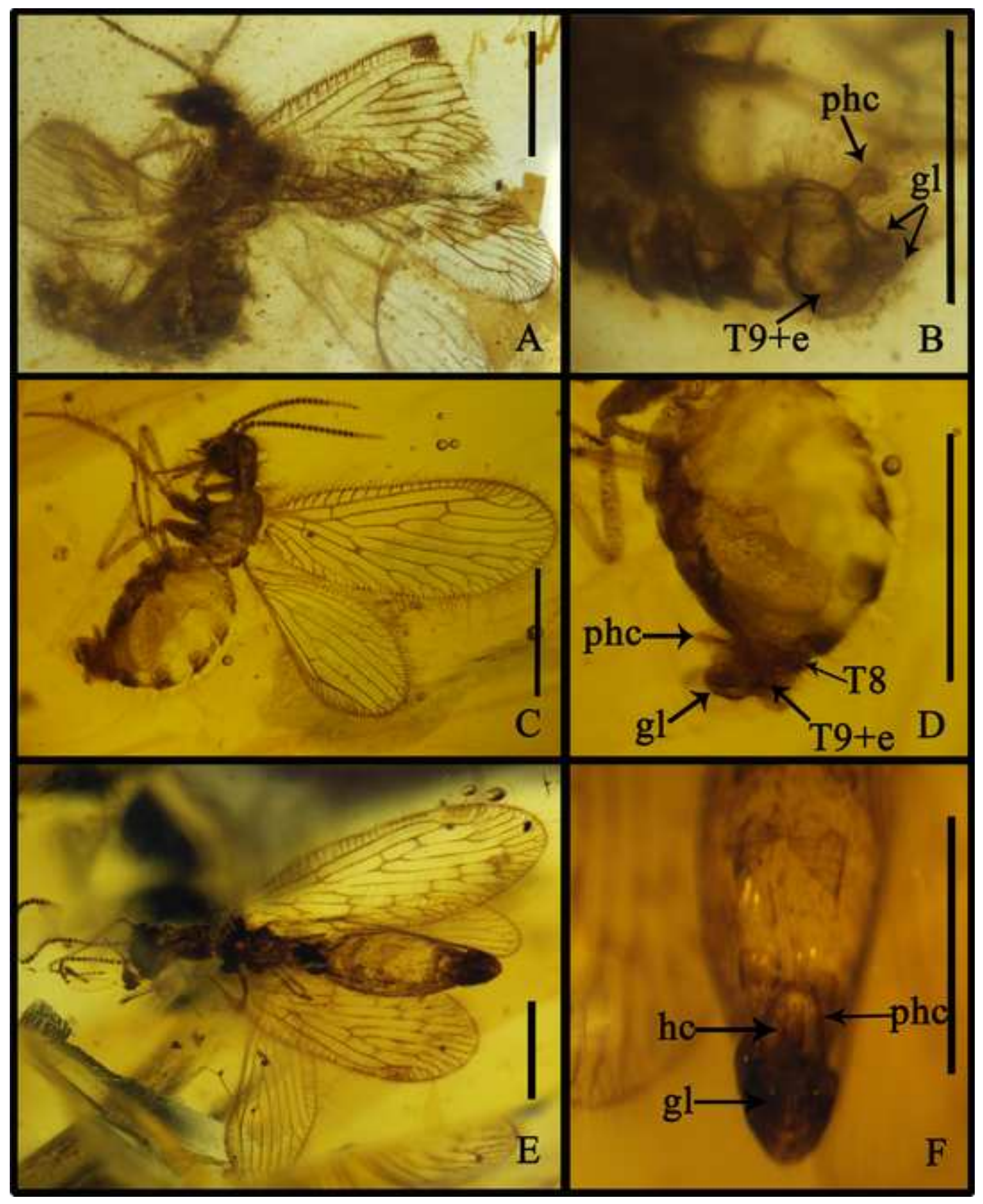

Figure 8

8

.

.

(⿸丆口
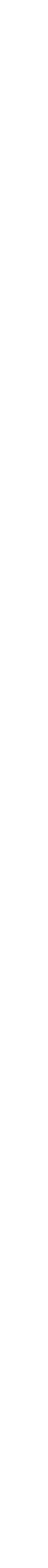
C 